\title{
OBSERVATIONS ON THE NESTING BEHAVIOR AND PREY OF GORYTINE WASPS IN TRINIDAD (HYMENOPTERA, SPHECIDAE)*
}

\author{
By E. MCC. Callan
}

13 Gellibrand Street, Campbell, Canberra, A.C.T., Australia

\section{INTRODUCTION}

The gorytine wasps comprise the tribe Gorytini of the sphecid subfamily Nyssoninae. They are a generalized group and all the higher Nyssoninae could have arisen from a gorytine ancestor (Bohart and Menke, 1976). Our knowledge of their ethology has been summarized by Evans (1966) and is based largely on studies in the Northern Hemisphere. Biologically these wasps are little known in the tropics or south temperate regions, although some recent observations have been made in Australia and Argentina (Evans and Matthews, 1971, 1973). The nests are mass-provisioned with Homoptera, mainly Fulgoroidea, Cicadidae, Cicadellidae, Cercopidae and Membracidae, and, in Australia, Eurymelidae, but there are few records of the prey of tropical species.

I have found a number of Gorytini nesting in Trinidad, West Indies. Several species belong to the wide-ranging genus Hoplisoides and one to Sagenista, a closely related neotropical genus described by Bohart (1967). My observations provide new data on tropical species and confirm in large part what is known elsewhere of gorytine nesting behavior and prey preferences.

\section{ECOlogy of Nesting Sites}

Gorytine wasps nest in the ground, generally in bare, sandy soil and dig relatively shallow, normally multicellular nests. Much of Trinidad is forested or alienated for plantation crops and suitable areas for ground-nesting species are limited. All the nesting sites I found in Trinidad were in small exposed areas free from vegetation and most were in close proximity to forest.

In the foothills of the Northern Range nesting sites were found in the following areas: in lower montane rain forest in the Caura Valley, about $5 \mathrm{~km}$ north of Tacarigua; at the edge of a cacao plantation adjacent to similar forest in the Maracas Valley, some

* Manuscript received by the editor January 28, 1977. 
$6 \mathrm{~km}$ north of St. Augustine; and in evergreen seasonal forest at Cumaca, about $14 \mathrm{~km}$ north of Sangre Grande. In both the Caura and Maracas Valleys the nesting sites were near streams. Wasps were also found nesting in the foothills of the Central Range in evergreen seasonal forest at Talparo and Mundo Nuevo, about 16 and $20 \mathrm{~km}$ respectively south of Arima.

In two areas nesting sites were encountered at some distance from forest. One was at St. Augustine, a residential area with many planted trees $13 \mathrm{~km}$ east of Port of Spain. The other was at North Post, an open windswept hillside cleared of forest on the North Coast, about $10 \mathrm{~km}$ northwest of Port of Spain and within $500 \mathrm{~m}$ of the Caribbean Sea.

\section{Hoplisoides umbonicida Pate}

Hoplisoides umbonicida was described by Pate (1941) as a new species based on material I sent him from Trinidad in December 1940. The type specimens, together with 3 cocoons and a specimen of the treehopper prey Umbonia spinosa (Fabricius) (Membracidae), are in the Academy of Sciences of Philadelphia, as are probably 2 further wasps, one with a specimen of the same treehopper prey pinned with it, which I sent Pate in March 1942.

H. umbonicida is a medium-sized species (female $12 \mathrm{~mm}$ long, male $10 \mathrm{~mm}$ long), black but broadly marked with yellow on the head, thorax and abdomen. I first encountered it in the Caura Valley on 5 August 1938. A female burdened with a large treehopper was seen descending slowly to its nest in a narrow sandy beach deposited near a natural swimming-pool by the fast-flowing Tacarigua (or Caura) River. The nesting site was in rather coarse sand and was a true stream-side locality. The wasp appeared to drop silently out of the sky coming down ever more slowly as it lost height. Descent was more or less vertical from a height of about $2 \mathrm{~m}$. Related species are known to approach the nest obliquely, slowly and from a considerable height. The wasp opened the nest quickly and plunged in precipitously with the prey. The nest was excavated and the burrow found to be oblique and no more than $10 \mathrm{~cm}$ long. Three cells were dug out each containing a cocoon, and the female was found in the nest with its prey in process of provisioning a fourth cell. It is possible that further cells were present with stored prey and developing wasp larvae, but they were not found. 
The prey carried by the female was an adult hoplophorine treehopper Umbonia spinosa. This is the largest membracid known from Trinidad, $15 \mathrm{~mm}$ long, bright green with 6 vivid red longitudinal lines on the enlarged pronotum, which is drawn out dorsally into a sharp point, and bears a resemblance to a large plant thorn. It is a rare species in Trinidad, where it has only once been found feeding on indigenous woody shrubs or small trees of the genus Inga (Leguminosae), which do not themselves bear thorns and often occur in the understory of lower montane rain forest. The prey was actually larger than the wasp itself, and was clasped venter to venter by the female's middle legs with the head foremost and the enlarged pointed pronotum projecting downwards. Had the sand not been friable at the entrance to the nest it would have been difficult for the female to enter so rapidly with such large prey. As it was, in entering the nest the prey was displaced rearwards to the hind legs of the wasp and the sharp point of the pronotum made a clearly perceptible furrow in the sand at the nest entrance as the prey was drawn in.

Three cocoons were removed from the nest. They were ovoid, greyish, hard and smooth, rounded at the anterior end and pointed at the posterior end. Two were about $12 \mathrm{~mm}$ long and $5.5 \mathrm{~mm}$ wide and the other about $10 \mathrm{~mm}$ long and $5 \mathrm{~mm}$ wide. There were no pores in the walls of the cocoons. Female wasps emerged from the larger cocoons and a male from the smaller one, and represented the type, one of the female paratypes and the allotype respectively on which Pate based his description of $H$. umbonicida.

My second encounter with what I took to be this species was on 25 January 1942 at Talparo, where I found it nesting in the fine, friable sand on the floor of a sandpit. Several wasps were observed provisioning their nests with large membracids. They descended slowly to the closed nest entrance, which they opened quickly with the fore-legs, and disappeared from sight rapidly with their prey. Two females were captured, one with an adult of Umbonia spinosa. No nests were excavated. The 2 females and specimen of prey, which were sent to Pate in March 1942 , came from this source.

\section{Hoplisoides vespoides ( F. Smith)}

In 1973 material from Trinidad (as well as a female from Paramaribo, Surinam collected on 13 October 1938 by D. C. Geijskes) 
was studied by Professor R. M. Bohart, who identified it as $H$. vespoides. These specimens were taken between 1942 and 1951 at 5 different nesting sites in the Northern and Central Ranges. Two females collected in March 1935 in Trinidad without specific locality by D. Vesey-FitzGerald are also in the Museum of Comparative Zoology, Harvard University.

On 16 May 1942 I discovered several individuals of this species nesting in a small clearing in the forest at Cumaca. The wasps were in the course of digging their nests in a flat area of friable sand at the base of a sandy bank. The fore-legs were used in digging the nest. The female came out of the entrance backwards, scraping out the sand with the fore-legs, which worked together, and sweeping it away. When disturbed the wasp rose silently into the air. Then it descended slowly to the sand near the nest, walked a few steps to the entrance with wings elevated at a strong angle to the body, entered the nest and continued digging. Three females were captured, but none were observed bringing in prey. The wasps were nesting in company with Cerceris dilatata Spinola and Bicyrtes variegata (Olivier). The former species was provisioning its nest in the sandy bank with buprestid prey, and several nests of the latter were intermingled with those of $H$. vespoides.

On 4 April 1943 I found this species nesting in the fine. loose sand on the floor of a sandpit at Mundo Nuevo. Several wasps were seen provisioning their nests. Two females were captured, both carrying adults of the large treehopper Umbonia spinosa. They descended slowly and silently to their nests holding the prey with their middle legs tightly clasped beneath the body and passed it to the hind legs as they entered the nest. The wasps were nesting in association with Bembecinus agilis (F. Smith), which was storing its nests with cicadellid prey.

I encountered on 25 December 1943 what appeared to be this species nesting in the floor of the same sandpit at Talparo, where I had found H. umbonicida nesting in 1942. A single female was collected, which was identified by Professor Bohart as H. fuscus (Taschenberg), a species described from Brazil. Pate (1941) stated, in describing $H$. umbonicida, that it was somewhat intermediate between $H$. fuscus and $H$. robustus (Handlirsch), agreeing with the former in appearance, but being apparently most closely allied to the latter. In connection with studies on other wasps, I visited the Talparo sandpit again on 26 July 1945 and noticed a single 
female busily digging its nest. This individual was captured and identified as $H$. vespoides.

Nesting sites of this species were subsequently discovered in 2 further areas. One was at North Point, where on 11 March 1949 I encountered several females provisioning their nests. I took a female carrying a large, probably 5th instar nymph of Umbonia spinosa. This was the only occasion on which I found a nymph and not an adult membracid being used as prey. The other site was in the Maracas Valley, where on 20 January 1951 I captured a female digging its nest in sandy soil near the Maracas River.

\section{Hoplisoides iridipennis (F. Smith)}

This is a small black species with a pair of conspicuous transverse yellow bands on the dorsum of the thorax. It ranges from Mexico to Brazil. I first encountered it at St. Augustine on 31 October 1943 when a female was observed entering its nest in a flat sandy area alongside a path. The wasp was captured and the nest excavated. The burrow was oblique and descended for about $8 \mathrm{~cm}$. A single cell was found containing 3 adult tragopine treehoppers, all Horiola picta (Coquebert) (Membracidae). The prey was lying ventral side up and showed no sign of movement. No egg was found. $H$. picta is a widely distributed gregarious treehopper, $4.5 \mathrm{~mm}$ long, with dark and light brown markings. It is known as the cacao podhopper and is one of the commonest membracids associated with cacao (Theobroma cacao L.) in Trinidad, where it is regarded as a minor pest. Aggregations of nymphs and adults are often found feeding on the petioles of flowers and the stalks of developing cacao pods.

I next discovered this wasp on 3 June 1949 at Talparo. A female was seen flying slowly down to its nest carrying an adult darnine treehopper Darnoides brunneus (Germar), a smooth, olive-green, solitary species, about $5.5 \mathrm{~mm}$ long. The prey was clasped by the wasp's middle legs and held ventral side up, head foremost. The nest was not excavated. It was located in friable sand on the floor of the same sandpit in which $H$. umbonicida and $H$. vespoides were found nesting.

My third encounter with $H$. iridipennis was on 31 August 1949 in the Maracas Valley. A female was seen approaching its nest carrying an adult membracine treehopper Erechtia bicolor Walker. 
The membracid, held tightly below its body by the wasp, was rather small, and I was not successful in observing prey carriage closely, but the middle legs were almost certainly used to hold the prey. The nest was unfortunately not located. E. bicolor is a brownish, gregarious treehopper, $4 \mathrm{~mm}$ long, found on mango (Mangifera indica L.) in Trinidad, where aggregations of adults and nymphs have been noticed feeding and causing characteristic lesions on inflorescences.

Finally, I reported (Callan, 1954) as Gorytes sp., a female which was almost certainly $H$. iridipennis, taken on 7 April 1944 at Cristóbal Colón, Estado Sucre, Venezuela.

$H$. iridipennis clearly preys on Membracidae like many other members of the genus. The 3 species of adult treehoppers recorded as prey were distinctly smaller than the wasp and several individuals are undoubtedly stored in each cell, how many is uncertain as only one nest was excavated. Two species, Horiola picta and Erechtia bicolor are gregarious, and their colonies are invariably attended by ants, mainly Azteca, Dolichoderus and Wasmannia, which exploit them for their honeydew. The ants evidently deter neither the gorytine wasps from capturing their prey nor the mymarid and trichogrammatid parasites, which commonly attack the eggs of these treehoppers.

\section{Hoplisoides denticulatus (Packard)}

This species is characterized by short thickened antennae and was originally described from Louisiana. It ranges widely through the United States and into Mexico. Krombein (1959) captured a female $7.5 \mathrm{~mm}$ long on 30 July 1958 in North Carolina with a deltocephaline nymph $5.5 \mathrm{~mm}$ long probably in the 5th instar (Cicadellidae).

I took a female in Trinidad at St. Augustine on 1 February 1948, which considerably extends the known distribution of the species. It was not found nesting and nothing is known of its prey in Trinidad.

\section{Sagenista brasiliensis (Shuckard)}

This is a black wasp about $10 \mathrm{~mm}$ in length with basally infuscate wings. Originally described as a Gorytes, it was transferred by Bohart (1967) to a new genus Sagenista, closely related to 
Hoplisoides. The genus is neotropical, ranging from Mexico to southern Brazil, and comprises 6 species, most of them known only from Brazil. Nesting behavior is largely unknown, but Bohart and Menke (1976) reported "one female Sagenista from Rio de Janeiro (at Mus. Washington) pinned with a large adult membracid, presumably its prey."

$S$. brasiliensis is the only species to have been studied in the field. Williams (1928) found that it was abundant near Belém, Brazil and excavated a nest at Jabaty, about $100 \mathrm{~km}$ from Belém. One cell contained 6 immature fulgoroid bugs, 4 being Dictyopharidae and 2 Issidae, and in another cell were 5 adult and one immature Issidae, representing various species. A species of Flatidae was also stored by the wasp. Williams noted that the egg was attached laterally to the thorax of the prey. The cocoons were more or less enveloped by the remains of the prey and described as "gently rounded at the fore end and more narrowed and drawn out a little, nipple-like at the base."

S. brasiliensis was collected in Trinidad in 1935 by D. VeseyFitzGerald. as 3 males and 3 females so labelled without specific locality are in the Museum of Comparative Zoology. I first came across this rather unobtrusive species on 12 March 1945 at the 11 th mile post - the highest point $(550 \mathrm{~m})$ - of the ArimaBlanchisseuse road. Here in typical upper montane rain forest the Northern Range is crossed by the road at a col between the summits of Mount El Tucuche and Morne Bleu. Two females, evidently searching the vegetation for prey, were taken in bright sunshine at about 1000 hours on low plants bordering the roadside. Unfortunately they were not seen capturing prey nor was the nesting site found.

I later discovered this species nesting in the Maracas Valley, where on 17 August 1949 a male and several females were collected. Little is known of the behavior of male gorytine wasps and this is the only species in which I took a male near the nesting site. A female was seen entering its nest carrying prey held tightly clasped beneath its body. A fly Spilogona sp. (Muscidae) was captured flying closely behind the wasp as it approached the nest burdened by its prey. Nest associates of gorytine wasps are usually Sarcophagidae, and the shadowing behavior of this satellite fly does not imply that it is an inquiline, and is of unknown significance. The nest, which was in friable sandy soil, was excavated and 2 cells found at the end of a short burrow about $6 \mathrm{~cm}$ long. 
One cell was provisioned with 4 adult fulgoroid bugs and a single adult treehopper (Membracidae). The second cell contained 5 adult fulgoroid bugs. The prey was completely paralyzed, but capable of slight twitching movement of the legs on stimulation. A large egg about $1.0 \mathrm{~mm}$ long was attached for its full length ventrally at the base of the legs of one of the prey. On 31 August 1949 I visited the Maracas Valley again and took several females, one of which was carrying an adult fulgoroid bug with its ventral side up held below the body by the wasp's middle legs. The nest was not found and presumably the entrance is kept closed when the wasp is away.

On 16 September 1949 another nesting site was found in a sandy bank near the previous one in the Maracas Valley. A wasp was seen leaving its nest, which was dug out, and 3 cells, each containing a cocoon, were unearthed. As the sand crumbled readily, it is possible that they belonged to more than one nest, but this is unlikely. Attached to the cocoons by strands of fungus mycelium were the wings, eaten-out head capsules, parts of the legs, and other remains of the homopterous prey. The cocoons were ovoid, pale brown, hard and smooth, rounded at the anterior and more pointed at the posterior end, which was drawn out into a nipplelike protuberance like the distal end of a lemon. They varied in length from 9 to $10 \mathrm{~mm}$ and in width from 4 to $4.5 \mathrm{~mm}$. No pores were present in the walls of the cocoons. Three female wasps emerged from the cocoons by biting off a cap at the anterior end leaving a rough edge.

$S$. brasiliensis provisions its nest almost exclusively with Fulgoroidea of various families except for a single treehopper (Membracidae), most of the prey ranging in size from about 4 to $8 \mathrm{~mm}$ (Table 1). Nests are multicellular and several prey, both adults and nymphs, are stored in each cell. The achilid Koloptera callosa was described from Panama and recorded by Fennah (1945) from Trinidad. The issid Thionia mammifera, and the flatids Epormenis fuliginosa and Euhyloptera corticalis were described from Trinidad (Fennah, 1945). E. fuliginosa is known only from the island, where it occurs commonly with related species as a minor pest on cacao and coffee (Coffea arabica L.). The smiline treehopper Ceresa vitulus is a wide-ranging, greenish, cryptic solitary membracid, about $5 \mathrm{~mm}$ long, with the pronotum bearing 2 sharp humeral spines. In Trinidad it is often found on cacao and many other plants. 
Table 1. Prey records for Sagenista brasiliensis

\begin{tabular}{lcc}
\multicolumn{1}{c}{ Species of prey } & Locality & Observer \\
ACHILIDAE & & \\
Koloptera callosa Metcalf & Trinidad & Callan \\
DELPHACIDAE & & \\
Punana sp. & Trinidad & Callan \\
DICTYOPHARIDAE & & \\
Dictlophara sp. & Brazil & Williams (1928) \\
ISSIDAE & & \\
Thionia mammifera Fennah & Trinidad & Callan \\
Thionia sp. & Brazil & Williams (1928) \\
Spp. indet. & Brazil & Williams (1928) \\
FLATIDAE & & \\
Epormenis fuliginosa (Fennah) & & Callan \\
Euhlyloptera corticalis Fennah & Trinidad & Callan \\
Flatormenis sp. & Trinidad & Callan \\
Sp. indet. & Trinidad & Williams (1928) \\
MEMBRACIDAE & Brazil & \\
Ceresa vitulus (Fabricius) & & Callan
\end{tabular}

\section{DISCUSSION}

I have thought it best to treat Hoplisoides umbonicida and $H$. vespoides as distinct species. Both are listed by Bohart and Menke (1976), and Professor Bohart confirms (1976, in litt.) that he considers umbonicida to be a species separate from vespoides. Pate was a meticulous worker and described both sexes of umbonicida in detail, and it seems unlikely that he would have recognized it as a new entity unless he was reasonably certain it was distinct from related species. It would be interesting, however improbable, should two similar sympatric species occur in Trinidad, nesting possibly under slightly different conditions, and both provisioning their nests, so far as known, exclusively with Umbonia spinosa and no other prey. Until Pate's holotype and vespoides are compared, it will not be possible to resolve the problem.

Many neotropical gorytines apparently mimic social vespids of the tribe Polybiini. Pate (1941) pointed out that H. umbonicida bears a striking superficial resemblance to the velutina phase of Brachygastra lecheguana (Latreille) - a phase now identified 
with relatively newly emerged wasps. This widespread species is not found in Trinidad, but its congener B. bilineolata Spinola occurs commonly there. Vesey-FitzGerald (1939) reported that in Trinidad "an undetermined species of Gorytes which is of rare occurrence bears a very close resemblance to" a wasp which is now known as Stelopolybia pallipes (Olivier). This aggressive polybiine is essentially a forest species and is common in Trinidad. There is little doubt that Vesey-FitzGerald's "undetermined Gorytes" is the species represented by 2 specimens bearing his name in the Museum of Comparative Zoology, identified by Professor Bohart as $H$. vespoides.

Most Gorytini prey on an array of species belonging to a single homopterous family. Hoplisoides iridipennis is typical of its genus in taking several species of Membracidae, but H. umbonicida and $H$. vespoides exhibit a degree of specificity in that they prey, so far as known, only on one species Umbonia spinosa. Sagenista brasiliensis preys on 6 homopterous families including Membracidae, and in this respect parallels the genus Ochleroptera, which is known to prey on 5 families. This provides ethological support for Bohart's separation on morphological grounds of the genus Sagenista from Hoplisoides.

Multicellular mass-provisioned nests are characteristic of Gorytini. Unfortunately the nests of only 3 species were excavated. In $H$. umbonicida the burrow was about $10 \mathrm{~cm}$ long and 4 cells were found. Because of the large size of the prey, probably only 3 or 4 individuals are stored in each cell. In $H$. iridipennis the burrow was about $8 \mathrm{~cm}$ long and a single cell was found containing 3 prey. It is unlikely that this species makes unicellular nests; either this was the first cell of a series and others would be added later, or other cells were present and were not found. The 2 nests of $S$. brasiliensis that were dug out were comparatively shallow, one being only about $6 \mathrm{~cm}$ long. They had 2 and 3 cells respectively, and 5 prey were found in both of 2 cells that were probably fully provisioned.

The Talparo sandpit provided favorable nesting conditions for digger wasps and was exploited by numerous species. Occupying the vertical walls of the sandpit were Trachypus petiolatus (Spinola), Cerceris dilatata Spinola and C. callani Krombein, and nesting with $H$. umbonicida and other Hoplisoides species in the flat sandy floor were, among others, Tachytes 
fraternus Taschenberg, Tachysphex inconspicuus (Kirby), Bembecinus agilis (F. Smith) and Bicyrtes discisa (Taschenberg). A study of this complex of wasps will be published elsewhere.

Two species of Nyssonini, which are cleptoparasites of gorytine and larrine wasps, were encountered at Talparo. Three females of Zanysson dives (Handlirsch) were captured flying low over the floor of the sandpit and walking on the surface of the sand exploring holes or irregularities, but were not seen to enter nests. Zanysson is a genus known to attack Tachytes, and it may well be that $Z$. dives is a parasite of $T$. fraternus. A male probably of Epinysson zapotecus (Cresson) was also taken in the sandpit. Several members of this genus are known to be parasites of Hoplisoides, and it seems likely that E. zapotecus parasitizes one or other of the Hoplisoides species nesting at Talparo.

\section{ACKNOWLEDGMENTS}

I am indebted to Professor R. M. Bohart for identifying the wasps. Dr. R. G. Fennah kindly named the Fulgoroidea, Professor W. D. Funkhouser, Dr. Louise M. Russell and Dr. P. S. Broomfield the Membracidae, and Dr. R. J. Gagné the Spilogona sp. The wasps and prey (except for Hoplisoides umbonicida) have been deposited in the Museum of Comparative Zoology, Harvard University. I am grateful to Professor H. E. Evans for depositing this material on my behalf and to Ms. Margaret K. Thayer for providing me with data relating to the specimens.

\section{Literature Cited}

BOHAKT, R. M.

1967. New genera of Gorytini. Pan-Pacif. Ent. 43: 155-161.

Bohart, R. M., and A. S. MenKe

1976. Sphecid wasps of the world: a generic revision. Univ. California Press. Berkeley, Calif. 695 pp.

CALIAN, E. MCC.

1954. Observations on Vespoidea and Sphecoidea from the Paria Peninsula and Patos Island, Venezuela. Bol. Ent. Venez. 9: 13-27.

Evans, H. E.

1966. The Comparative Ethology and Evolution of the Sand Wasps. Harvard Univ. Press, Cambridge, Mass. 526 pp.

Evans, H. E., and R. W. Matthews

1971. Nesting behaviour and larval stages of some Australian nyssonine sand wasps (Hymenoptera: Sphecidae). Aust. J. Zool. 19: 293-310. 
1973. Observations on the nesting behavior of South American sand wasps (Hymenoptera). Biotropica 6: 130-134.

FENNAH, R. G.

1945. The Fulgoroidea, or lanternflies, of Trinidad and adjacent parts of South America. Proc. U. S. Natn. Mus. 95: 411-520.

Krombein, K. V.

1959. Biological notes on some ground-nesting wasps at Kill Devil Hills, North Carolina, 1958, and additions to the faunal list (Hymenoptera, Aculeata). Proc. Ent. Soc. Wash. 61: 193-199.

PATE, V. S. L.

1941. Two new species of sphecoid wasps from Trinidad (Hymenoptera:Aculeata). Notulae Nat., Acad. Nat. Sci. Phila. No. 91.8 pp.

Vesey-FitzGerald, D.

1939. Colour-pattern resemblances between wasps and other insects in Trinidad. Proc. R. Ent. Soc. London 14(A): 103-105.

Williams, F. X.

1928. Studies in tropical wasps - their hosts and associates. Bull. Exp. Sta. Hawaii Sugar Pl. Assn., Ent. Ser. 19: 1-179. 


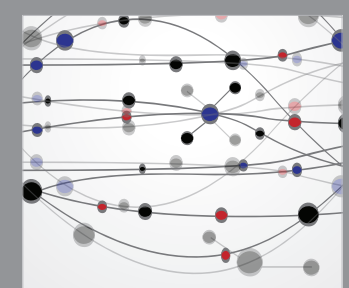

The Scientific World Journal
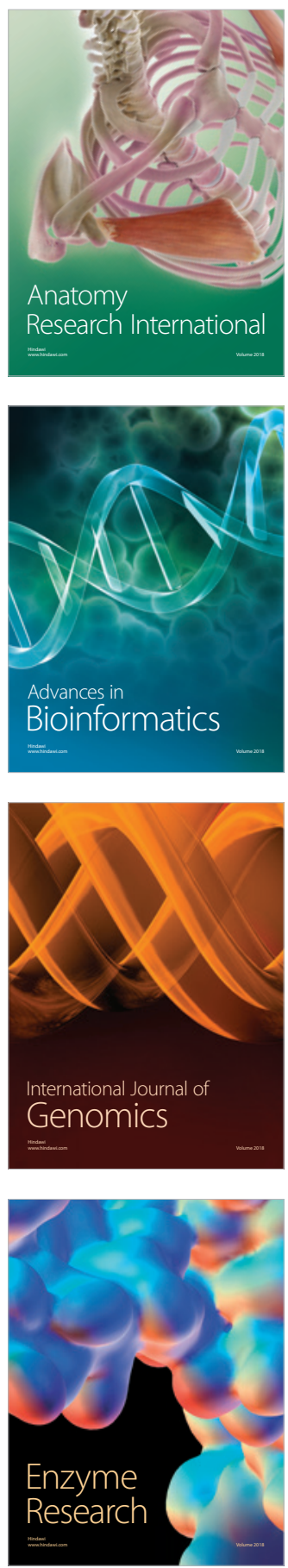
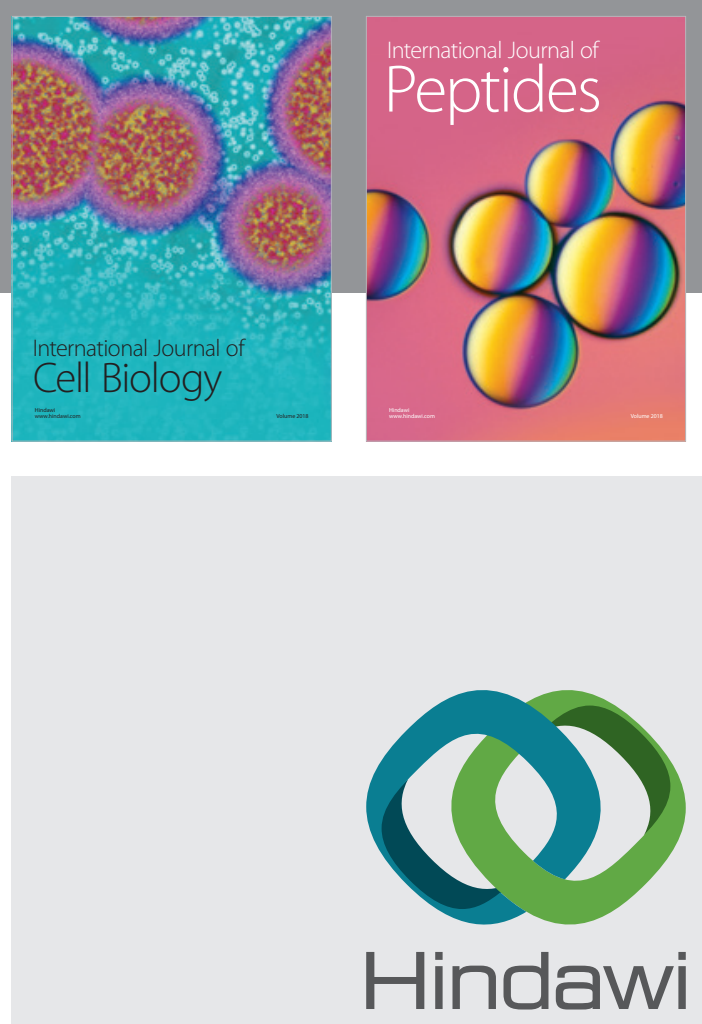

Submit your manuscripts at

www.hindawi.com
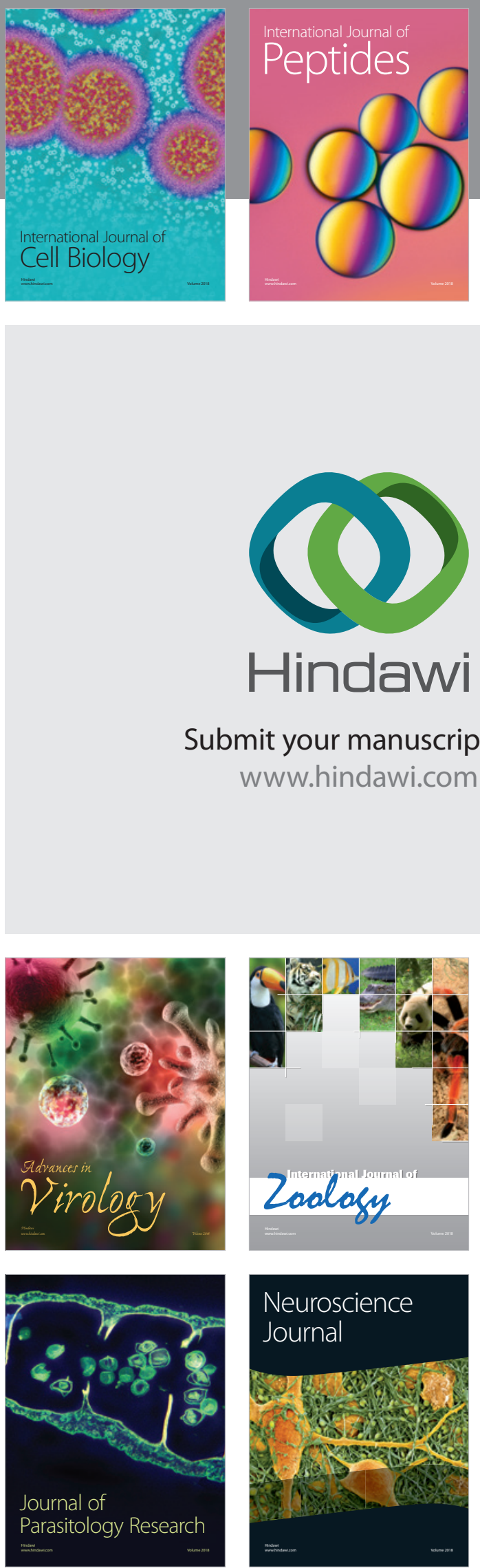
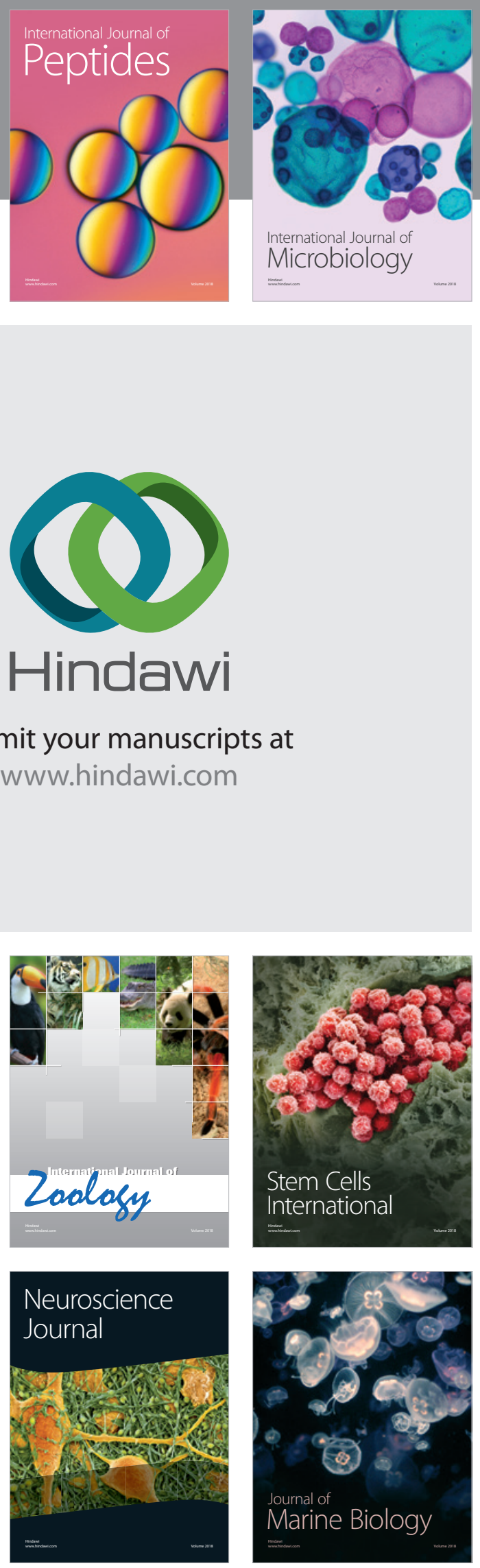
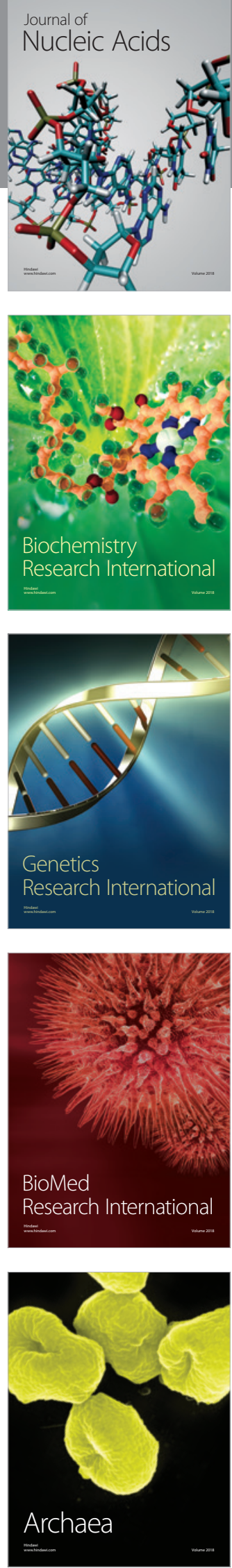